\title{
HUBUNGAN ANTARA WORK-FAMILY CONFLICT DAN WORK-FAMILY BALANCE DENGAN KEPUASAN PERNIKAHAN PADA ISTRI YANG MENJALANI DUAL-EARNER FAMIL Y
}

\author{
Adriana Soekandar Ginanjar ${ }^{1 *}$, Indira Primasari ${ }^{1}$, Rizqika Rahmadini ${ }^{1}$, Rima Woro Astuti ${ }^{1}$ \\ ${ }^{1}$ Fakultas Psikologi, Universitas Indonesia, Depok 16424, Indonesia
}

*)E-mail: adriana.soekandar@ui.ac.id

\begin{abstract}
Abstrak
Kepuasan pernikahan pada pasangan yang menjalani dual-earner family memiliki tantangan yang besar, terutama bagi istri, akibat tingginya stress yang bersumber dari pekerjaan maupun pernikahan dan keluarga. Penelitian ini bertujuan untuk menganalisis hubungan work-family conflict dan work-family balance terhadap kepuasan pernikahan pada istri yang menjalani dual earner family. Penelitian ini menggunakan pendekatan kuantitatif dengan desain cross-sectional. Kepuasan pernikahan diukur menggunakan Couple Satisfaction Index, work-family conflict diukur dengan menggunakan Work-Family Conflict Scale, sementara work-family balance diukur dengan Work-Family Balance Scale. Responden dalam penelitian ini adalah 181 istri yang merupakan pegawai penuh waktu di Jabodetabek, dipilih dengan teknik convenience sampling. Teknik korelasi Pearson digunakan sebagai metode dalam melakukan pengujian hipotesis. Hasil penelitian menunjukkan bahwa workfamily conflict berhubungan negatif secara signifikan dengan kepuasan pernikahan, terutama dalam dimensi work-intervening with family $(r=-0,346 ; p<0,01)$. Sementara itu, terdapat korelasi yang positif antara work-family balance dengan kepuasan pernikahan pada istri dalam dual-earner family $(r=0,294 ; p<0,01)$. Penelitian ini menunjukkan bahwa menjalankan peran sebagai pekerja, istri, dan ibu dalam waktu yang bersamaan bukan hal yang mudah dan dapat menurunkan kepuasan pernikahan.
\end{abstract}

Kata kunci: dual-earner family, kepuasan pernikahan, wanita bekerja, work-family balance, work-family conflict

\section{The Relationship between Work-Family Conflict and Work-Family Balance with Marital Satisfaction of Wife in Dual-Earner Families}

\begin{abstract}
Marriage satisfaction among couples in dual earner family faces greater challenges because of high stress from work and family, especially for the wives due to dominant role in the family. The aim of this cross-sectional study was to analyze the correlation of work-family conflict and work-family balance on wives' marital satisfaction in dual earner family. Marriage satisfaction was measured by the Couple Satisfaction Index, work-family conflict was measured using the Work-Family Conflict Scale, while work-family balance was measured using the Work-Family Balance Scale. The participants, selected with convenience sampling, were 181 wives who were full time employees and worked in Jabodetabek. Pearson Correlation technique was used for testing hypotheses. The results showed that work-family conflict was negatively related to marital satisfaction, especially work-intervening with family $(r=-0,346 ; p<0.01)$. Meanwhile, work-family balance had positive correlation with marriage satisfaction $(r=0,294 ; p<0.01)$. This research showed that fulfilling the role as a worker, wife, and mother at the same time is not easy and can decrease marital satisfaction.
\end{abstract}

Keywords: dual-earner family, marital satisfaction, working women, work-family conflict, work-family balance

\section{PENDAHULUAN}

Jumlah tenaga kerja di Indonesia terus meningkat dari tahun ke tahun. Menurut Badan Pusat Statistik, pada bulan Februari tahun 2019 tercatat 136,18 juta pekerja, meningkat sebesar 2,24 juta dibandingkan satu tahun sebelumnya. Persentase tertinggi adalah pada pekerja penuh waktu yaitu sebesar 69,96 persen. Peningkatan ini tidak hanya terjadi pada tenaga kerja pria melainkan juga tenaga kerja wanita, walaupun jumlah tenaga kerja wanita lebih sedikit dibandingkan pria (BPS, 2019). Tingkat partisipasi wanita berpendidikan tinggi dalam pekerjaan juga cenderung meningkat, tidak hanya pekerja wanita yang belum menikah, tetapi juga wanita yang telah menikah dan memiliki anak. Keputusan istri untuk bekerja didasarkan pada alasan dan pertimbangan tertentu, mulai dari pemenuhan kebutuhan 
ekonomi keluarga hingga pemenuhan aktualisasi diri. Kondisi ini tentunya memengaruhi struktur keluarga, dari struktur tradisional menuju egaliter, dari single-earner menjadi dual-earner. Dual-earner family adalah pasangan baik suami maupun istri bekerja dan mendapatkan penghasilan, serta keduanya bersama-sama menjaga kehidupan berumah tangga (Steil, 2009).

Menjalani dual-earner family memiliki dampak positif dan negatif bagi pasangan. Dampak positifnya adalah peningkatan kondisi finansial yang dapat mendorong meningkatnya kualitas kesehatan, kualitas perawatan anak, dan kemampuan orang tua untuk menabung demi masa depan anak (Zaimah, 2019). Selain itu, masing-masing pasangan memiliki identitas diri yang lebih baik ketika berkegiatan dalam pekerjaan karena di dalam pekerjaan mereka mendapatkan pengakuan atas performa kerja yang baik (Masterson \& Hoobler, 2014).

Di sisi lain, menjalani dual-earner family tidaklah mudah, terutama bagi wanita. Tekanan dan tuntutan peran dalam domain pekerjaan dan keluarga sangat berbeda dan membuat partisipasi dalam satu peran lebih sulit dibandingkan peran lainnya (Minnotte, Minnotte, \& Bonstrom, 2014; Pedersen \& Kilzer, 2013; Toffoletti \& Starr, 2016). Salah satu masalah yang dihadapi dual-earner family adalah kemampuan dalam menyeimbangkan peran dalam keluarga dan pekerjaan (Barnett, Del Campo, Del Campo, \& Steiner, 2003).

Ketidakseimbangan antara kehidupan keluarga dan pekerjaan dapat membuat pasangan dualearner mengalami kelelahan dan stres berlebihan. Apabila individu tidak dapat menyeimbangkan peran-peran tersebut maka individu tersebut akan rentan terhadap stres akibat konflik peran (Chen \& Li, 2012). Sejumlah penelitian telah membuktikan bahwa pada aspek kehidupan keluarga, tuntutan berbagai peran dapat memengaruhi kepuasan keluarga, kepuasan hidup, dan kepuasan pernikahan (Carlson, Kacmar, \& Williams, 2000; Park \& Fritz, 2015; Waismel-Manor, Levanon, \& Tolbert, 2016; Xie, Shi, \& Ma, 2017).

Pada pasangan yang telah menikah, salah satu aspek penting di dalam pernikahan adalah kepuasan pernikahan. Kepuasan pernikahan adalah evaluasi subjektif pasangan yang telah menikah terhadap hubungan romantis yang sedang dijalani (Fincham \& Rogge, 2010; Fincham, Rogge, \& Beach, 2018; Norton, 1983) dan dipandang sebagai evaluasi menyeluruh, bukan menekankan pada dimensi penyusun kepuasan pernikahan (Norton, 1983). Kepuasan pernikahan ini merupakan salah satu tujuan terpenting dalam pernikahan (Heshmati, Behnampour, Arabameri, Khajavi, \& Kohan, 2016) karena akan mengarah pada peningkatan kualitas pernikahan yang merupakan prediktor dari kebahagiaan dan kesehatan (Finkel, Slotterm, Luchies, Walton, \& Gross, 2013). Sebaliknya, ketidakpuasan dalam pernikahan dapat mengarah pada perceraian (Apostolou, Constantinou, \& Anagnostopoulos, 2018; Fallahchai, Fallahi, \& Randall, 2019).

Banyaknya dampak dari kepuasan pernikahan menyebabkan pentingnya untuk mencari tahu faktor apa saja yang berperan dalam tercapainya kepuasan pernikahan, khususnya pada istri yang menjalani dual-career family karena fokus dan perhatiannya terbagi antara pernikahan, keluarga dan pekerjaan. Apabila tidak dapat menyeimbangkan peran-peran tersebut maka istri akan rentan terhadap stres akibat konflik peran (Chen \& Li, 2012).

Lebih lanjut, tuntutan dan stressors pada satu peran (pekerjaan) akan menyebabkan konflik pada peran lainnya (keluarga) yang kemudian dapat menurunkan tingkat kepuasaan pada kedua peran tersebut (Bagherzadeh et al., 2016; Pattusamy \& Jacob, 2015). Sementara itu, hasil penelitian van Steenbergen, Kluwer, dan Karney (2014) menunjukkan bahwa pengalaman yang didapatkan pada pekerjaan akan berdampak pada pernikahan, seperti stres kerja dapat menurunkan kepuasan pernikahan.

Di Indonesia, secara umum masyarakatnya lebih banyak yang memegang budaya patriarki, artinya laki-laki memiliki kontrol dan kekuasaan yang lebih besar dibandingkan wanita dalam berbagai aspek kehidupan di masyarakat (Sakina \& Asiah, 2007). Adanya pengaruh budaya menyebabkan istri dalam dual-earner family dituntut untuk lebih mampu membagi waktu yang dimilikinya untuk pekerjaan, pasangan, merawat orang tua, dan anak. Walaupun bekerja, istri tetap memegang tanggung jawab lebih besar dalam pengasuhan anak dan mengurus rumah tangga dibandingkan suami. Keharusan untuk menjalankan berbagai peran tersebut akhirnya memunculkan tekanan yang saling bertentangan dari domain pekerjaan dan keluarga. Akibatnya, partisipasi dalam peran keluarga menjadi lebih sulit karena beban pekerjaan atau sebaliknya. Kondisi ini dikenal dengan istilah work-family conflict (Armstrong, Atkin-Plunk, \& Wells, 2015; Liu et al., 2015). 
Work-family conflict merupakan bentuk dari konflik peran yang muncul dari tekanan peran yang bertolak belakang antara domain pekerjaan dan keluarga sehingga partisipasi pada salah satu peran menjadi lebih sulit akibat peran lainnya (Armstrong et al., 2015; Liu et al., 2015). Kondisi ini berpengaruh langsung kepada keluarga dan memberikan dampak kepada kehidupan pernikahan (Carroll, Hill, Yorgason, Larson, \& Sandberg, 2013). Pada keluarga dengan suami dan istri yang samasama bekerja, kondisi menjalankan beberapa peran dalam waktu bersamaan merupakan beban mental yang lebih berat pada istri dibandingkan pada suami. Istri yang bekerja dibebani oleh dua tanggung jawab yang sama penting dan berat di waktu yang bersamaan. Akibat adanya tuntutan dari pekerjaan dan keluarga, istri dapat mengalami konflik akibat kurangnya waktu untuk menjalankan kedua peran, ketidakcocokan perilaku pada kedua peran, dan ketegangan yang muncul dalam menjalankan masing-masing peran (Tazekand, Nafar dan Keramati, 2013)

Work-family conflict merupakan variabel yang memiliki dua arah yang terdiri dari workintervening with family (WIF) atau kondisi ketika pekerjaan mengganggu keluarga dan familyintervening with work (FIW) atau kondisi ketika keluarga mengganggu pekerjaan (Beigi, Shirmohammadi, \& Kim, 2016; Mercado \& Dilchert, 2017). Fellows, Chiu, Hill, dan Hawkins (2015) menemukan adanya hubungan negatif antara work-family conflict dengan kepuasan pernikahan. Hal ini sejalan dengan temuan bahwa kepuasan pernikahan merupakan bagian dari kehidupan keluarga dan yang paling terkena dampak negatif dari workfamily conflict (Bagherzadeh et al., 2016).

Penelitian-penelitian terdahulu menunjukkan hasil yang berbeda tentang arah work-family conflict. Menurut Keene dan Reynolds (2005), wanita cenderung mengalami arah FIW lebih banyak dibandingkan pria dan lebih merasakan stres akibat kekurangan waktu yang muncul akibat adanya work-family conflict. Sementara Frone (2003) menemukan bahwa pekerjaan memiliki lebih banyak efek negatif terhadap keluarga karena secara umum WIF dilaporkan lebih sering terjadi dibandingkan FIW.

Tuntutan pekerjaan yang tinggi dapat mengganggu kepuasan pernikahan melalui hilangnya sumber daya (resources) seperti energi fisik, waktu, dan energi mental (Ahlin, Westerlund, Griep, \& Hanson, 2017; Ferguson, Carlson, Zivnuska, \& Whitten, 2012; Langdon \& Sawang, 2018; Santa-Maria et al., 2017). Istri merasa mendapat beban pekerjaan yang berat di tempat kerja sehingga saat berada di rumah akan merasa sangat tertekan akibat tidak memiliki waktu yang cukup banyak untuk keluarga (Carlson et al., 2000; Van Steenbergen et al., 2014). Beban yang berat pada pekerjaan tersebut dapat menyita pikiran dan tenaga, sementara itu istri masih memiliki tanggung jawab kepada keluarga. Kondisi tersebut menyebabkan performa dalam menjalankan tanggung jawab keluarga dapat menurun. Tuntutan peran yang berlebihan tersebut menyebabkan munculnya role strain yang dapat berujung kepada konflik peran (Creary \& Gordon, 2016; Nohe, Meier, Sonntag, \& Michel, 2015).

Work-family conflict terdiri dari tiga bentuk, yaitu: time-based conflict, strain-based conflict, dan behavior-based. Time-based conflict adalah kurangnya waktu yang dibutuhkan untuk berpartisipasi pada satu peran karena banyak digunakan untuk peran lainnya. Misalnya, beban waktu yang tinggi dalam pekerjaan mengganggu peran sebagai orang tua di keluarga. Strain-based conflict muncul ketika ketegangan dari salah satu peran berakibat sulitnya penyesuaian pada peran lainnya, seperti misalnya kinerja di tempat kerja menurun akibat ketegangan menghadapi masalah keluarga. Sementara behavior-based conflict merupakan konflik yang terjadi akibat adanya ketidakcocokan tingkah laku antara satu peran dengan peran lainnya. Sebagai contoh, seorang manajer dituntut untuk bertindak tegas, stabil secara emosional, dan cukup asertif, sementara di dalam keluarga individu dituntut untuk bersikap hangat, fleksibel, dan cenderung mengalah (Armstrong et al., 2015; Liu et al., 2015).

Di sisi lain, terdapat dual-earner family yang tetap memiliki kepuasan pernikahan yang baik walau masing-masing pasangan bekerja. Penelitian skala besar yang dilakukan oleh Yucel (2017) menunjukkan bahwa family enrichment, yaitu bagaimana pekerjaan berpengaruh positif terhadap keluarga dan demikan sebaliknya, berhubungan secara positif dengan kepuasan pernikahan. Jadi tidak selamanya pekerjaan berdampak negatif terhadap kehidupan pernikahan. Disamping itu, seimbangnya peran antara pekerjaan dan keluarga juga dapat mencegah role strain yang mengarah pada stres dan penurunan kepuasan pernikahan (Barnett et al., 2003). Oleh karena itu, penting untuk menjaga keseimbangan peran antara pekerjaan dan keluarga yang disebut dengan istilah work-family balance. 
Keberhasilan dalam memenuhi ekspektasi tersebut dikarenakan adanya negosiasi serta pembagian kerja yang baik antara individu dengan pasangan dan rekan kerja (Ferguson, Carlson, Kacmar, \& Halbesleben, 2016; Pluut, llies, Curşeu, \& Liu, 2018). Negosiasi yang dimaksud adalah membicarakan tanggung jawab yang harus dilaksanakan. Tanggung jawab dalam keluarga dan pekerjaan perlu dibicarakan dengan rekan-rekan terkait, agar individu dapat menyesuaikan antara kemampuan dan tanggung jawab yang harus dilaksanakan (Pluut et al., 2018).

Dalam domain keluarga, work-family balance berperan terhadap keberfungsian dan kepuasan keluarga. Hal tersebut dikarenakan kepuasan pernikahan merupakan salah satu komponen dari kepuasan keluarga. Oleh karenanya, dipercaya bahwa work-family balance juga memiliki hubungan dengan kepuasan pernikahan. Hal ini didukung oleh penelitian yang dilakukan Barnett et al. (2003) dan Chen dan Li (2012) bahwa keseimbangan peran berasosiasi positif dengan kepuasan pernikahan.

Berdasarkan uraian di atas dapat disimpulkan bahwa istri yang bekerja rentan terhadap workfamily conflict yang berdampak negatif pada kepuasan pernikahan. Namun demikian, kemampuan istri untuk menyeimbangkan kedua peran dapat mempertahankan dan meningkatkan kepuasan pernikahan. Mengingat semakin meningkatnya jumlah wanita yang menjalani dual-carreer family di Indonesia dan belum banyaknya penelitian terkait kedua kondisi tersebut maka penting untuk meneliti hubungan dari work-family conflict dan work-family balance terhadap kepuasan pernikahan. Penelitian ini difokuskan pada wanita bekerja penuh waktu di daerah perkotaan (Jakarta, Bogor, Depok, Tangerang dan Bekasi) dengan demikian hasilnya dapat memberikan gambaran tentang kondisi dualcareer family di wilayah tersebut.

Penelitian ini bertujuan untuk mengetahui hubungan antara work-family conflict dan workfamily balance dengan kepuasan pernikahan pada istri yang menjalani dual earner family. Hipotesis yang ingin diuji dalam penelitian ini adalah terdapat hubungan negatif yang signifikan antara work-family conflict dengan kepuasan pernikahan pada istri dalam dualearner family dan terdapat hubungan positif yang signifikan antara work-family balance dengan kepuasan pernikahan pada istri dalam dual-earner family.

\section{METODE}

Penelitian ini menggunakan pendekatan kuantitatif dengan disain cross-sectional. Adapun kriteria subjek penelitian adalah wanita dengan status menikah yang berasal dari dualearner family, berusia 20-60 tahun dan bekerja serta bertempat tinggal di Jabodetabek. Responden berpendidikan minimal SMA atau setara, bekerja penuh waktu (minimal 35 jam dalam seminggu), sudah bekerja di perusahaan saat ini minimal satu tahun, dan memiliki suami yang juga bekerja penuh waktu. Dengan menggunakan aplikasi G-Factor version 3.1.9.2 pada effect size sebesar 0,3 , koefisien alpha error probability sebesar 0,05 , dan power sebesar 0,95 pada one-tail, jumlah responden dari penelitian ini adalah minimal 111. Jumlah responden yang berhasil didapatkan pada penelitian ini adalah 181 responden sehingga memenuhi jumlah minimal responden.

Proses pengambilan sampel dilakukan dengan metode nonprobability sampling dengan teknik convenience sampling atau dikenal dengan nama lain accidental sampling atau haphazard sampling. Convenience sampling adalah proses pengambilan sampel berdasarkan kemudahan akses dalam mendapatkan responden (Gravetter \& Forzano, 2012). Kelemahan dari teknik ini adalah rentan terhadap bias karena peneliti hanya memiliki sedikit kontrol terhadap representasi populasi. Akan tetapi, teknik ini adalah salah satu teknik yang paling sering digunakan karena lebih mudah, tidak mahal, dan tidak menyita waktu yang banyak dibandingkan teknik lainnya. Untuk mengatasi kelemahan dari teknik convenience sampling, peneliti memastikan bahwa sampel yang dipilih sesuai dengan karakteristik responden. Disamping itu peneliti juga memberikan deskripsi yang jelas mengenai bagaimana proses pengambilan sampel dan gambaran dari sampel yang diperoleh (Gravetter \& Forzano, 2012).

Peneliti melakukan pengambilan data setelah memperoleh ethical clearance dari Tim Kaji Etik Fakultas Psikologi Universitas Indonesia. Prosedur pengambilan data dilakukan dengan dua cara. Pertama, kuesioner disebarkan secara langsung dalam bentuk booklet kepada orang-orang yang sesuai dengan karakteristik responden. Peneliti meminta bantuan kepada teman dan saudara untuk membantu menyebarkan kuesioner. Kedua, kuesioner dikirim secara online melalui tautan googleform, disebarkan menggunakan media sosial. Informasi terkait perekrutan sampel berisi gambaran singkat penelitian, karakteristik 
responden, dan kuesioner online. Dengan cara tersebut dapat diperoleh karakteristik sampel yang sesuai dengan yang ditetapkan oleh peneliti.

Work-Family Conflict didefinisikan sebagai salah satu bentuk konflik antar peran yang terjadi pada saat tekanan dari keluarga dan pekerjaan saling bertolak belakang sehingga mengakibatkan partisipasi pada salah satu peran menyulitkan partisipasi dalam peran yang lainnya (Armstrong et al., 2015; Liu et al., 2015). Variabel ini diukur menggunakan instrumen Work-Family Conflict Scale (WFCS) yang dikembangkan oleh Carlson et al. (2000) dengan menggunakan definisi Work-Family Conflict dari Greenhaus dan Beutell (1985). WFCS tersusun dari 18 pernyataan yang mencakup enam dimensi, yaitu Strain-based WIF, Strain-based FIW, Behavior-based WIF, Behavior-based FIW, Time-based WIF, dan Time-based FIW. Respon responden diukur melalui skala Likert dari rentang skor 1 hingga 5 ("sangat tidak setuju" hingga "sangat setuju"). Semakin tinggi skor yang didapat maka semakin tinggi juga tingkat work-family conflict yang dirasakan dan begitu pula sebaliknya. Alat ukur ini memiliki item validity berkisar antara 0,437-0,972 yang dilakukan dengan metode corrected item-total correlation dengan nilai reliabilitas nilai Cronbach's alpha sebesar 0,779 .

Work-family balance merupakan ketercapaian seluruh ekspektasi dari peran dalam pekerjaan dan peran dalam keluarga yang dijalankan bersama-sama (Omar \& Zakaria, 2015). Workfamily balance merupakan skor total yang diperoleh dari kuesioner Work-Family Balance Scale (Carlson, Grzywacz, \& Zivnuska, 2009). Skala ini terdiri dari 6 pernyataan dan respon responden diukur menggunakan skala Likert dengan rentang 1-5 ("sangat tidak setuju" hingga "sangat setuju"). Validitas masingmasing pernyataan adalah diatas 0,77 yang diukur dengan metode corrected item-total correlation dengan nilai Cronbach's alpha sebesar 0,93.

Kepuasan pernikahan didefinisikan sebagai evaluasi global tentang keadaan pernikahan seseorang (Norton, 1983) Alat ukur yang digunakan untuk mengukur kepuasan pernikahan adalah Couple Satisfaction Index (CSI) (Funk dan Rogge, 2007). Kuesioner CSI menggunakan enam poin skala Likert dengan rentang $0-5$, yaitu sangat tidak benar, sedikit benar, cukup benar, kebanyakan benar, hampir sepenuhnya benar, dan sepenuhnya benar. Dalam penelitian ini digunakan $\mathrm{CSI}-16$ (terdiri dari 16 pernyataan) yang telah diadaptasi oleh Melissa (2015). Validitas CSI-16 versi adaptasi berkisar 0,270 sampai 0,751 , yang diukur dengan metode corrected item-total correlation dengan nilai Cronbach's alpha sebesar 0,906.

CSI-16 dibagi kedalam lima bagian dan memiliki lima jenis respon. Setiap bagian memiliki jumlah pernyataan dan bentuk respon yang berbeda-beda. Bagian satu mengukur derajat kebahagiaan dalam hubungan, bagian dua mengukur seberapa jauh relasi dengan pasangan dirasakan berjalan dengan baik, dan bagian tiga mengukur sejauh mana hubungan dengan pasangan dirasakan positif. Pemenuhan kebutuhan dari hubungan dan pasangan serta perasaan subjek tentang hubungannya masig-masing diukur pada bagian empat dan lima. Skoring CSI dilakukan dengan cara menjumlahkan respon dari seluruh jawaban. Rentang skor dari skala ini adalah 081. Skor CSI dibawah 51,5 mengindikasikan terdapat ketidakpuasan yang nyata dalam hubungan (Funk \& Rogge, 2007).

Analisis data dalam penelitian ini menggunakan statistik deskriptif untuk mengetahui gambaran demografis dan masing-masing variabel utama yakni kepuasan pernikahan, work-life conflict, dan work life balance responden. Peneliti menggunakan perhitungan korelasi Pearson untuk mengetahui apakah terdapat hubungan pada variabel yang diteliti. Sementara itu, untuk melakukan ketegorisasi terhadap hasil skor variabel work-family conflict dan work-family balance, dilakukanlah analisis dengan metode hypothetical mean. Berdasarkan kategorisasi tersebut, batas pisah untuk skor work-family conflict adalah 41 sehingga responden yang memiliki skor $\geq 41$ dapat dikategorikan memiliki work-family conflict yang tinggi, sementara responden yang memiliki skor < 41 dapat dikategorikan memiliki work-family conflict yang rendah. Adapun pada variabel work-family balance, responden yang memiliki skor $<15,16$ $-20, \geq 21$ dapat dikategorikan memiliki workfamily balance di tingkat rendah, sedang, dan tinggi. Untuk seluruh prosedur analisis, foftware analisis data yang digunakan dalam penelitian ini adalah aplikasi IBM SPSS Version 20.0.

\section{HASIL}

\section{Karakteristik Istri}

Jumlah responden yang berhasil didapatkan dalam penelitian ini, yaitu 212 responden. Namun, data yang dapat diolah berjumlah 181 data. 
Tabel 1 Gambaran umum responden penelitian $(n=181)$

\begin{tabular}{|c|c|c|c|}
\hline $\begin{array}{c}\text { Karakteristik } \\
\text { responden }\end{array}$ & Kategori & $\begin{array}{l}\text { Frekue } \\
\text { nsi (n) }\end{array}$ & $\begin{array}{l}\text { Distrib } \\
\text { usi (\%) }\end{array}$ \\
\hline \multirow[t]{2}{*}{ Usia } & $20-39$ & 137 & 75,70 \\
\hline & $40-60$ & 44 & 24,30 \\
\hline \multirow{4}{*}{$\begin{array}{l}\text { Pendidikan } \\
\text { terakhir }\end{array}$} & SMA/SMK/Sed & 20 & 11,00 \\
\hline & D1-D3 & 18 & 9,90 \\
\hline & $\mathrm{D} 4 / \mathrm{S} 1$ & 106 & 58,60 \\
\hline & S2-S3 & 37 & 20,40 \\
\hline \multirow{5}{*}{$\begin{array}{l}\text { Usia } \\
\text { pernikahan }\end{array}$} & $\leq 5$ tahun & 90 & 49,70 \\
\hline & $6-10$ tahun & 34 & 18,80 \\
\hline & 11-15 tahun & 25 & 13,80 \\
\hline & 16-20 tahun & 19 & 10,50 \\
\hline & $>20$ tahun & 13 & 7,20 \\
\hline \multirow[t]{3}{*}{ Anak } & Tidak memiliki & 27 & 14,90 \\
\hline & anak & 154 & 85,10 \\
\hline & тлетпाк апак & & \\
\hline \multirow{2}{*}{$\begin{array}{l}\text { Tinggal } \\
\text { serumah } \\
\text { dengan }\end{array}$} & Keluarga inti & 121 & 66,90 \\
\hline & Keluarga besar & 60 & 33,10 \\
\hline \multirow{5}{*}{$\begin{array}{l}\text { Lokasi tempat } \\
\text { kerja }\end{array}$} & Jakarta & 103 & 56,90 \\
\hline & Bogor & 30 & 16,60 \\
\hline & Depok & 9 & 5,00 \\
\hline & Tangerang & 22 & 12,20 \\
\hline & Bekasi & 17 & 9,40 \\
\hline \multirow{3}{*}{$\begin{array}{l}\text { Masa kerja di } \\
\text { tempat saat } \\
\text { ini }\end{array}$} & $<2$ tahun & 23 & 12,70 \\
\hline & 2-10 tahun & 105 & 58,00 \\
\hline & $>10$ tahun & 53 & 29,30 \\
\hline \multirow{6}{*}{$\begin{array}{l}\text { Jenis } \\
\text { pekerjaan }\end{array}$} & Karyawan & & \\
\hline & swasta & 117 & 6460 \\
\hline & $\begin{array}{l}\text { Pegawai negeri } \\
\text { sipil }\end{array}$ & 38 & 21,00 \\
\hline & Karyawan & 19 & 10,50 \\
\hline & BUMN & 7 & 390 \\
\hline & $\begin{array}{l}\text { Lain-lain } \\
\text { (Dokter } \\
\text { Guru) }\end{array}$ & $y$ & 3,90 \\
\hline \multirow{2}{*}{$\begin{array}{l}\text { Jam } \\
\text { kerja/minggu }\end{array}$} & $35-40$ & 127 & 70,20 \\
\hline & $>40$ & 54 & 29,80 \\
\hline \multirow{4}{*}{$\begin{array}{l}\text { Penghasilan/b } \\
\text { ulan }\end{array}$} & $<\operatorname{Rp} 3.000 .000$ & & \\
\hline & > Rp3.000.000 & 7 & 3,90 \\
\hline & Rp 10.000 .000 & 116 & 64,10 \\
\hline & $>_{10.000 .000} R p$ & 58 & 32,00 \\
\hline
\end{tabular}

Sejumlah kuesioner tidak dapat diolah karena responden ternyata tidak sesuai dengan kriteria yang sudah ditetapkan, seperti misalnya bekerja kurang dari 35 jam per minggu, suami tidak bekerja, dan responden tidak bekerja di wilayah Jabodetabek.

Berdasarkan Tabel 1 dapat dilihat bahwa sebagian besar responden dalam penelitian ini berada dalam kelompok usia dewasa muda, yaitu 20-39 tahun dengan lebih dari separuh responden berpendidikan D4 atau S1. Selain itu, hampir separuh dari responden $(49,70 \%)$ memiliki usia pernikahan berkisar 1-5 tahun, walaupun ada sejumlah kecil responden yang telah menikah lebih dari 20 tahun. Keseluruhan responden bekerja di daerah Jabodetabek dengan jumlah terbesar bekerja di Jakarta.

Selanjutnya, sebanyak 58 persen responden sudah bekerja di perusahaan saat ini selama 210 tahun dan jenis pekerjaan terbanyak adalah karyawan swasta (64,60\%). Hasil lain menunjukkan bahwa tujuh dari sepuluh responden bekerja antara 35-40 jam/minggu dan sisanya lebih dari $40 \mathrm{jam} / \mathrm{minggu}$. Pada aspek penghasilan, sebagian besar $(64,61 \%)$ mengaku mendapatkan penghasilan antara Rp3.000.000 sampai Rp10.000.000 setiap bulannya.

\section{Kepuasan Pernikahan}

Hasil penelitian menunjukkan, terdapat variasi yang cukup besar pada tingkat kepuasan pernikahan istri. Sebagian besar istri $(84,5 \%)$ merasa puas dengan pernikahan mereka, yaitu memiliki skor di atas 51,5 . Hanya 28 orang $(15,5 \%)$ yang menyatakan tidak puas dalam pernikahan saat ini. Hasil ini menunjukkan bahwa para istri yang menjalankan peran-peran sebagai karyawan, ibu, dan istri dalam waktu yang bersamaan tetap merasa puas dengan pernikahan yang mereka jalani.

\section{Work-Family Conflict}

Mayoritas istri memiliki work-family conflict yang tergolong tinggi, yaitu sebanyak 50,80 persen responden terkategori sebagai istri bekerja dengan work-family conflict tinggi. Dengan demikian dapat dikatakan bahwa sebagian besar istri yang berasal dari dual-earner family mengalami konflik peran antara peran sebagai karyawan dengan peran sebagai istri/ibu.

Tabel 2 Gambaran umum prosentase tingkat kepuasan pernikahan, work-family conflict, dan work-family balance

\begin{tabular}{llrr}
\hline \multicolumn{1}{c}{ Aspek } & Kategori & \multicolumn{1}{c}{ Skor } & $\begin{array}{c}\text { Presentase } \\
(\%)\end{array}$ \\
\hline Kepuasan & Tidak & $<51.5$ & 15,5 \\
pernikahan & Puas & $\geq 51.5$ & 84,5 \\
& Puas & $<41$ & 49,20 \\
Work-family & Rendah & $\geq 41$ & 50,80 \\
conflict & Tinggi & $<15$ & 3,3 \\
Work-family & Rendah & $16-20$ & 26 \\
balance & & $\geq 21$ & 20,7 \\
& Sedang & & \\
& Tinggi & & \\
\hline
\end{tabular}




\section{Work-Family Balance}

Pada aspek work-family balance, mayoritas responden memiliki skor yang tinggi $(M=23.06$, $\mathrm{SD}=3,488)$. Sedangkan skor minimum yang diperoleh adalah sebesar 12 dan skor maksimum sebesar 30. Berdasarkan kategorisasi yang dilakukan mayoritas responden yaitu sebesar 70,7 persen memiliki tingkat work-family balance yang tinggi.

\section{Hubungan antara Work-Family Conflict dengan Kepuasan Pernikahan}

Hasil analisis data (Tabel 3) menunjukkan, ada hubungan negatif yang signifikan antara workfamily conflict dengan kepuasan pernikahan pada istri dalam dual earner family $(r=0,346$; $p$ $<0,01)$. Hasil ini memperlihatkan, peningkatan work-family conflict akan diikuti dengan penurunan kepuasan pernikahan, sementara penurunan work-family conflict akan mengarah pada kenaikan kepuasan pernikahan. Selain itu, sebanyak 11,9 persen varians kepuasan pernikahan dapat dijelaskan oleh work-family conflict, sedangkan 88,1 persen sisanya merupakan kontribusi dari faktor-faktor lain. Berdasarkan hasil perhitungan regresi berganda dapat dilihat bagaimana arah workfamily conflict berpengaruh pada kepuasan pernikahan. Hasilnya menunjukkan bahwa WIF (work-intervening family) memiliki pengaruh negatif yang signifkan terhadap kualitas pernikahan dengan $\beta=-0,632, \quad p=0,002$ $(p<0,05)$. Artinya, konflik yang diakibatkan oleh dampak stres pekerjaan terhadap keluarga lebih memengaruhi menurunnya kepuasan pernikahan dibandingkan dengan stres keluarga yang berpengaruh negatif terhadap pekerjaan.

Tabel 3 Analisis work-family conflict dengan kepuasan pernikahan

\begin{tabular}{|c|c|c|c|}
\hline Variabel & $r$ & $p$ & r2 \\
\hline $\begin{array}{l}\text { Work-family conflict dan } \\
\text { kepuasan pernikahan }\end{array}$ & $0,346^{* *}$ & 0,000 & 0,119 \\
\hline Arah & $\begin{array}{r}\text { Beta } \\
(\beta)\end{array}$ & SE & Sig \\
\hline $\begin{array}{l}\text { Work intervening with } \\
\text { family (WIF) }\end{array}$ & $-0,632$ & 2,00 & 0,002 \\
\hline $\begin{array}{l}\text { Family intervening with } \\
\text { work (FIW) }\end{array}$ & $-0,224$ & 2,38 & 0,34 \\
\hline Bentuk & $\begin{array}{r}\text { Beta } \\
(\beta) \\
\end{array}$ & SE & Sig \\
\hline Time-based & $-0,170$ & 0,311 & 0,585 \\
\hline Strain-based & $-0,636$ & 0,330 & 0,056 \\
\hline Behavior-based & $-0,543$ & 0,222 & $0,016^{*}$ \\
\hline
\end{tabular}

Selanjutnya, work-family conflict memiliki tiga bentuk di dalamnya, yaitu time-based conflict, strain-based conflict, dan behavior-based conflict. Untuk memperdalam analisis dan mengetahui lebih lanjut mengenai peranan dari bentuk work-family conflict terhadap kepuasan pernikahan maka peneliti kemudian melakukan analisis regresi berganda.

Berdasarkan hasil analisis regresi berganda mengenai bentuk work-family conflict terhadap kepuasan pernikahan, diketahui bahwa behavior-based conflict memiliki $\beta=-0,543$, $p=0,016 \quad(p<0,05)$, yaitu merupakan prediktor terbesar pada kepuasan pernikahan jika dibandingkan dengan dua bentuk lainnya. Dengan demikian dapat disimpulkan bahwa konflik akibat perbedaan tuntutan peran antara pekerjaan dan keluarga dapat menurunkan kepuasan pernikahan.

Sebagai analisis tambahan, dilakukan analisis terhadap data demografis. Beberapa hasil penting yang ditemukan adalah bahwa responden yang berada pada usia dewasa muda (20-39 tahun) memiliki tingkat work-family conflict yang lebih tinggi dibandingkan mereka yang berada pada usia 40-69 tahun ( $\mathrm{t}=2,282$, $\mathrm{p}<0,5)$. Responden yang bekerja selama kurang dari 2 tahun memiliki work-family conflict yang lebih tinggi dibandingkan mereka yang bekerja dua tahun atau lebih $(F=3,321, p<0,05)$. Mereka yang bekerja lebih dari 40 jam/minggu juga ditemukan memiliki work-family conflict yang lebih tinggi dibandingkan mereka yang menghabiskan waktunya di tempat kerja antara $35-40$ jam/minggu $(t=-2,753, p<0,05)$.

\section{Hubungan antara Work-Family Balance dengan Kepuasan Pernikahan}

Berbeda dengan hasil work-family conflict, analisis hasil menunjukkan adanya korelasi yang positif antara work-family balance dengan kepuasan pernikahan pada istri dalam dualearner family $(r=0,294 ; \quad p<0,01)$. Artinya, semakin tinggi tingkat work family balance maka semakin tinggi pula kepuasan pernikahannya. Selanjutnya, untuk memperdalam analisis, peneliti juga melakukan analisis regresi berganda untuk mengetahui sumbangan peran kovariat terhadap variabel kepuasan pernikahan. Berdasarkan analisis regresi berganda dapat diketahui bahwa 8,9 persen varians kepuasan pernikahan dapat dijelaskan oleh work family balance dan sisanya oleh faktor-faktor lain. 
Tabel 4 Analisis tingkat work-family conflict berdasarkan data demografis responden

\begin{tabular}{|c|c|c|c|c|c|}
\hline $\begin{array}{l}\text { Karakteristik } \\
\text { responden }\end{array}$ & Kategori & $\mathrm{N}$ & M & Signifikansi & Keterangan \\
\hline \multirow[t]{4}{*}{ Usia } & & & & $t=2,282$ & \\
\hline & $20-39$ & 137 & 42,27 & $p=0,024$ & Signifikan \\
\hline & & & & $p<0,05$ & \\
\hline & $40-60$ & 44 & 38,11 & & \\
\hline \multirow[t]{4}{*}{ Jam kerja/minggu } & & & & $t=-2,753$ & \\
\hline & 35-40 jam & 127 & 39,87 & $p=0,007$ & Signifikan \\
\hline & & & & $p<0,01$ & \\
\hline & $>40$ jam & 54 & 44,54 & & \\
\hline \multirow[t]{5}{*}{ Masa kerja } & & & & $F=3,321$ & \\
\hline & $<2$ tahun & 23 & 43,38 & $p=0,038$ & Signifikan \\
\hline & & & & $p<0,05$ & \\
\hline & 2-10 tahun & 105 & 42,32 & & \\
\hline & $>10$ tahun & 51 & 38,19 & & \\
\hline
\end{tabular}

Analisis terhadap data demografis juga dilakukan pada variabel ini. Beberapa hasil penting adalah bahwa usia, jumlah anak, dan usia pernikahan berkorelasi dengan work-family balance pada istri yang menjalani dual-earner family. Korelasi usia dengan work-family balance adalah $0,228 \quad(p<0,01)$, yang menunjukkan bahwa semakin bertambah usia istri maka kemampuannya untuk mencapai keseimbangan antara pekerjaan dengan keluarga juga semakin tinggi.

Tabel 5 Korelasi variabel demografi, workfamily balance, dan kepuasan pernikahan

\begin{tabular}{lllllllll}
\hline $\begin{array}{c}\text { Variab } \\
\text { el }\end{array}$ & 1 & 2 & 3 & 4 & 5 & 6 & 7 \\
\hline Usia & & & & & & & &
\end{tabular}

\begin{tabular}{|c|c|c|c|c|c|c|}
\hline $\begin{array}{l}\text { Usia } \\
\text { (1) }\end{array}$ & -- & & & & & \\
\hline $\begin{array}{l}\text { Jumlah } \\
\text { anak } \\
\text { (2) }\end{array}$ & $\begin{array}{r}0,59 \\
2\end{array}$ & - & & & & \\
\hline $\begin{array}{l}\text { Pendidi } \\
\text { kan (3) }\end{array}$ & $\begin{array}{r}0,18 \\
3^{* *}\end{array}$ & $\begin{array}{r}0,13 \\
3^{*}\end{array}$ & - & & & \\
\hline $\begin{array}{l}\text { Usia } \\
\text { pernika } \\
\text { han (4) }\end{array}$ & $\begin{array}{r}0,90 \\
2^{\star *}\end{array}$ & $\begin{array}{r}0,61 \\
3^{* *}\end{array}$ & $\begin{array}{r}0,1 \\
10\end{array}$ & - & & \\
\hline $\begin{array}{l}\text { Jam } \\
\text { kerja } \\
\text { (5) }\end{array}$ & $\begin{array}{r}0,02 \\
4\end{array}$ & $\begin{array}{r}0,07 \\
3\end{array}$ & $\begin{array}{r}0,0 \\
52\end{array}$ & $\begin{array}{r}0,0 \\
22\end{array}$ & - & \\
\hline $\begin{array}{l}\text { Work- } \\
\text { family } \\
\text { balanc } \\
e(6)\end{array}$ & $\begin{array}{r}0,22 \\
8^{* *}\end{array}$ & $\begin{array}{r}0,14 \\
2^{*}\end{array}$ & $\begin{array}{r}0,1 \\
12\end{array}$ & $\begin{array}{r}0,2 \\
10\end{array}$ & $\begin{array}{r}0,0 \\
36\end{array}$ & - \\
\hline $\begin{array}{l}\text { Kepua } \\
\text { san } \\
\text { pernika } \\
\text { han (7) }\end{array}$ & $\begin{array}{r}0,01 \\
4\end{array}$ & $\begin{array}{r}0,06 \\
0\end{array}$ & $\begin{array}{r}0,0 \\
93\end{array}$ & $\begin{array}{r}0,0 \\
14\end{array}$ & $\begin{array}{r}0,0 \\
67\end{array}$ & $\begin{array}{r}0,29 \\
4^{\star *}\end{array}$ \\
\hline
\end{tabular}

Korelasi antara jumlah anak dengan workfamily balance sebesar $r=0,142(p<0,05)$, yaitu artinya semakin banyak jumlah anak yang dimiliki maka work-family balance semakin tinggi. Sementara korelasi antara usia pernikahan dengan work-family balance adalah sebesar $r=0,210,(p<0,01)$ yang menunjukkan bahwa work-family balance akan cenderung meningkat dengan bertambahnya usia pernikahan.

\section{PEMBAHASAN}

Hasil penelitian ini menunjukkan bahwa terdapat hubungan negatif yang signifikan antara work-family conflict dengan kepuasan pernikahan pada istri yang berada dalam pernikahan dual-earner family. Hasil ini mendukung penelitian sejumlah penelitian sebelumnya yang juga membuktikan adanya korelasi negatif antara work-family conflict dengan kepuasan hubungan, walaupun dalam istri bekerja yang berbeda (Fellows et al., 2015; Minnotte et al., 2014). Hasil penelitian ini juga sejalan dengan temuan yang menggunakan istri bekerja wanita bekerja di Indonesia (Handayani \& Harsanti, 2017). Hubungan negatif pada hasil penelitian yang telah lalu dan penelitian ini menunjukkan bahwa semakin tinggi work-family conflict maka diikuti dengan semakin rendah kepuasan pernikahan yang dirasakan oleh individu tersebut dan begitu juga sebaliknya.

Dengan demikian dapat disimpulkan bahwa semakin tinggi work-family conflict maka kepuasan pernikahan akan menurun, demikan juga sebaliknya. Keadaan konflik akibat memiliki beberapa peran memang seringkali dianggap sebagai mekanisme yang 
bertanggung jawab terhadap hubungan negatif antara domain keluarga dan pekerjaan (Poms, Fleming, \& Jacobsen, 2016). Ketika seseorang mengalami work-family conflict maka tekanan akibat waktu, ketegangan, atau perbedaan perilaku akan dialami. Pada akhirnya tekanantekanan tersebut dapat memunculkan kelelahan emosional yang kemudian berpengaruh terhadap kepuasan pernikahan individu tersebut (Poms et al., 2016).

Berdasarkan arah work-family conflict, dalam penelitian ini ditemukan bahwa arah workintervening with family (WIF) atau kondisi pekerjaan mengganggu keluarga menjadi prediktor yang signifikan pada kepuasan pernikahan istri dibandingkan dengan arah family-intervening with work (FIW). Temuan dalam penelitian ini berbeda dengan hasil penelitian Keene dan Reynolds (2005) yang menyatakan bahwa dibandingkan pria, wanita cenderung lebih banyak mengalami konflik keluarga yang mengganggu kinerja dalam pekerjaan atau family-intervening with work. Tingginya tingkat konflik pekerjaan yang berdampak negatif pada keluarga dapat disebabkan oleh beberapa hal. Salah satunya adalah tingginya tingkat keterlibatan pada pekerjaan dan banyaknya waktu yang digunakan untuk bekerja (Byron, 2005). Pada penelitian ini, responden yang dipilih adalah karyawan penuh waktu yang bekerja minimal $35 \mathrm{jam} / \mathrm{minggu}$, bahkan sebagian bekerja lebih dari $40 \mathrm{jam} / \mathrm{minggu}$. Kondisi ini menyebabkan waktu yang dimiliki istri untuk keluarganya menjadi terbatas. Selain itu, belum lagi kemacetan di kota besar yang harus dihadapi setiap hari, semakin mengurangi jumlah waktu dan energi yang dapat diberikan untuk keluarga.

Penelitian ini juga menunjukkan bahwa bentuk konflik yang menjadi prediktor signifikan terhadap kondisi kepuasan pernikahan pada istri dalam dual-earner family adalah behaviorbased conflict, yaitu yang terjadi ketika terdapat ketidaksesuaian perilaku antara satu peran dengan peran lainnya. Ketidaksesuaian perilaku tersebut membuat seseorang akhirnya menampilkan perilaku negatif seperti marah atau menarik diri sehingga akan berdampak kepada penurunan kepuasan pernikahan (Wortel, 2009). Dalam penelitian ini, mayoritas responden telah memiliki anak sehingga memiliki peran sebagai karyawan, istri dan juga ibu dalam waktu yang bersamaan. Penelitian ini menyumbangkan fakta bahwa tingginya perbedaan tuntutan diantara peran-peran tersebut mengarah pada menurunnya kepuasan pernikahan.
Selain itu, hasil penelitian juga menunjukkan adanya perbedaan signifikan pada tingkat workfamily conflict apabila dilihat berdasarkan usia. Responden yang berusia 20 hingga 39 tahun (masa dewasa muda) mengalami konflik yang lebih tinggi dibandingkan mereka yang berada pada masa dewasa madya. Perbedaan yang signifikan juga ditemukan pada jam kerja. Dari aspek jam kerja, responden yang menghabiskan lebih dari 40 jam per minggu memiliki tingkat konflik yang lebih tinggi. Kedua perbedaan pada tingkat work-family conflict tersebut dapat terjadi karena sebagian besar responden berada pada rentang usia dewasa muda, memiliki usia pernikahan 1-5 tahun, dan sudah memiliki anak. Akibatnya konflik peran yang dialami cenderung tinggi karena istri perlu mengalokasikan waktu, perhatian, dan tenaga untuk bekerja dan juga memelihara pernikahan dan mengurus anak. Waktu yang dihabiskan untuk mengurus anak, khususnya pada masa bayi, juga memiliki efek negatif pada penghasilan istri karena ia mengorbankan waktu dan energi untuk anaknya dibanding pada kariernya (Angelov, Johansson, \& Lindahl, 2016; Evers \& Sieverding, 2013; Molina, 2015)

Analisis terhadap variabel work-family balance dan kepuasan pernikahan menunjukkan hasil yang berlawanan dengan hubungan antara work-family conflict dan kepuasan pernikahan. Penelitian ini membuktikan bahwa work family balance dapat meningkatkan kepuasan pernikahan. Hasil ini mendukung dan memperkaya penelitian-penelitian sebelumnya yang menyatakan bahwa terdapat hubungan positif yang signifikan antara work-family balance dan kepuasan pernikahan (Barnett et al., 2003; Carlson et al., 2009; Chen \& Li, 2012).

Istri yang berasal dari dual-earner family dihadapkan pada berbagai tanggung jawab peran yang harus dijalani, yaitu peran untuk mengurus anak, mengurus rumah tangga, dan bertanggung jawab terhadap pekerjaan. Seringkali tuntutan dan tekanan dalam domain pekerjaan dan keluarga saling bertentangan sehingga membuat partisipasi dalam kedua domain semakin sulit (Minnotte et al., 2014). Keberhasilan dalam menyeimbangkan tuntutan dan tekanan peran akan mempermudah partisipasi dalam domain tersebut dan berdampak positif pada pernikahan.

Hasil penelitian tersebut sejalan dengan hasil penelitian Barnett et al. (2003) yang menunjukkan bahwa level work family balance yang dipersepsi oleh individu memengaruhi persepsi kualitas pernikahan yang sedang 
dijalani. Istri yang telah mencapai level balance dapat mengembangkan kemampuan pemecahan masalah dan lebih tahan terhadap stres. Ketika suatu masalah datang, maka individu dapat mencari solusi secara cepat dan dapat melihat suatu permasalahan dari berbagai sudut pandang (Chen \& Li, 2012). Penelitian ini juga sejalan dengan penelitian lain bahwa kemampuan membagi sumber daya secara merata berperan sebagai faktor penentu well-being (Carlson et al., 2009; Chen \& Li, 2012; Nohe et al., 2015). Dengan demikian, saat terjadi masalah dalam hubungan pernikahan yang dikarenakan urusan pekerjaan maka individu dapat menangani masalah tersebut dengan cepat sehingga masalah tidak menjadi berlarut larut sehingga kepuasan pernikahan tetap stabil bahkan dapat meningkat.

Penelitian ini juga menunjukkan bahwa usia responden berkorelasi positif dengan workfamily balance, yang artinya semakin tinggi usia responden maka semakin tinggi tingkat workfamily balance. Jika dikaitkan dengan tugas perkembangan, semakin dewasa seseorang maka tingkat conscientiousness yang dimiliki semakin tinggi, yang mungkin disebabkan oleh pengalaman kerja atau karena meningkatnya kematangan sosial dan stabilitas emosi yang semakin baik (Deepa, 2019; Leikas \& SalmelaAro, 2014). Dengan demikian, semakin dewasa seseorang maka pengetahuan mengenai bagaimana bertindak dan menyikapi kondisikondisi dalam hidup menjadi lebih baik. Ditinjau dari segi kognitif, mereka yang telah memasuki usia dewasa madya memiliki kemampuan integrative thought, artinya mereka mampu mengintegrasikan logika dengan intuisi dan emosi. Mereka juga menginterpretasikan informasi yang diperoleh menjadi sesuatu yang bermakna berdasarkan pengalaman hidup mereka. Dengan demikian, mereka akan lebih berhasil dalam mencapai keseimbangan dalam peran-perannya (Papalia \& Martorell, 2014).

Penelitian VanSteenbergen, Kluwer, dan Karney (2014) menemukan bahwa faktor terkait pekerjaan dan keluarga yang berperan dalam kepuasan pernikahan adalah work-family conflict dan work-family enrichment. Tingginya work-family conflict akan mendorong stres dan penurunan performa dalam menjalankan peran pada domain keluarga. Sebaliknya jika tingkat work-family enrichment tinggi maka akan mendorong kepuasan pernikahan. Pengalaman yang didapatkan dari pekerjaan dapat diterapkan ketika menjalankan tanggung jawab peran di dalam keluarga disamping juga meningkatkan pengaruh positif individu sehingga mendorong peningkatan performa dalam keluarga (van Steenbergen et al., 2014). Penelitian-penelitian tersebut mendukung hasil penelitian ini yang juga membuktikan bahwa work-family conflict berpengaruh pada penurunan kepuasan pernikahan sementara work-family balance meningkatkan kepuasan pernikahan.

\section{SIMPULAN DAN SARAN}

Berdasarkan hasil penelitian ini dapat disimpulkan bahwa terdapat hubungan negatif yang signifikan antara work-family conflict dengan kepuasan pernikahan. Adanya peningkatan pada work-family conflict akan diikuti dengan penurunan pada kepuasan pernikahan, demikian juga sebaliknya. Sementara itu, workfamily balance memiliki hubungan positif yang signifikan dengan kepuasan pernikahan. Dengan demikian, semakin tinggi work-family balance maka semakin tinggi pula kepuasan pernikahan yang dimiliki.

Keterbatasan pada penelitian ini adalah tidak dilibatkannya suami dalam pengambilan data padahal besar kemungkinan mereka juga mengalami konflik-konflik terkait pekerjaan dan keluarga dalam perkawinan yang lebih egaliter. Jumlah responden dalam penelitian ini juga perlu diperbanyak, terutama responden dari Jabodetabek yang bukan penduduk Jakarta, agar hasil penelitian lebih menggambarkan populasi yang dipilih. Disamping itu, cara pengambilan sampel dengan metode nonprobability sampling menghambat dilakukannya generalisasi hasil penelitian ini pada populasi. Keterbatasan lain dari penelitian ini adalah adanya dua cara penyebaran kuesioner, yaitu secara langsung dan secara online. Perbedaan ini kemungkinan memengaruhi kualitas data yang terkumpul dan memiliki efek pada hasil penelitian secara keseluruhan.

Berdasarkan hasil penelitian ini perlu dilakukan penelitian lanjutan untuk meneliti faktor-faktor lain dalam dual-earner family yang memengaruhi kepuasan pernikahan secara negatif dan positif, seperti stres internal dan eksternal, serta coping pada pasangan (dyadic coping). Bagi psikolog, hasil penelitian ini dapat menjadi panduan untuk memberikan psikoedukasi dan konseling kepada wanita bekerja tentang pentingnya mencari strategi mengatasi work-family conflict dan mencapai work-family balance dan juga menjalin kerjasama suami-istri dalam menjalankan peran sebagai orang tua. 


\section{DAFTAR PUSTAKA}

[BPS] Badan Pusat Statistik Provinsi DKI Jakarta. (2019). Keadaan Ketenagakerjaan Indonesia Februari 2019. Jakarta, ID: BPS Indonesia.

Ahlin, J. K., Westerlund, H., Griep, Y., \& Hanson, M. L. L. (2017). Trajectories of job demands and control: Risk for subsequent symptoms of major depression in the nationally representative Swedish Longitudinal Occupational Survey of Health (SLOSH). International Archives of Occupational and Environmental Health, 91(3), 263-272. doi:10.1007/s00420-017$1277-0$

Angelov, N., Johansson, P., \& Lindahl, E. (2016). Parenthood and the gender gap in pay. Journal of Labor Economics, 34(3), 545-579. doi:10.1086/684851.

Apostolou, M., Constantinou, C., \& Anagnostopoulos, S. (2018). Reasons that could lead people to divorce in an evolutionary perspective: Evidence from Cyprus. Journal of Divorce \& Remarriage, 60(1), 27-46. doi:10.1080/10502556 .2018.1469333.

Armstrong, G. S., Atkin-Plunk, C. A., \& Wells, J. (2015). The relationship between workfamily conflict, correctional officer job stress, and job satisfaction. Criminal Justice and Behavior, 42(10), 10661082. doi:10.1177/0093854815582221.

Bagherzadeh, R., Taghizadeh, Z., Mohammadi, E., Kazemnejad, A., Pourreza, A., \& Ebadi, A. (2016). Relationship of work-family conflict with burnout and marital satisfaction: Cross-domain or source attribution relations. Health Promotion Perspectives, 6(1), 31-36. doi:10.15171/ hpp.2016.05.

Barnett, K. A., Del Campo, R. L, Del Campo, D. S., \& Steiner, R. L. (2003). Work and family balance among dual-earner working-class mexican-americans: Implications for therapists. Contemporary Family Therapy, 25(4), 353-366.

Beigi, M., Shirmohammadi, M., \& Kim, S. (2016). Living the academic life: A model for work-family conflict. Work, 53(3), 459468. doi:10.3233/wor-152173.

Byron, K. (2005). A meta-analytic review of work-family conflict and its antecedents. Journal of Vocational Behavior, 67(2), 169198. doi:10.1016/j.jvb.2004.08.009
Carlson, D. S., Grzywacz, J. G., \& Zivnuska, S. (2009). Is work-family balance more than work-family conflict and enrichment?. Human Relations, 62(10), 1459-1486. doi:10.1177/001872670 9336500.

Carlson, D. S., Kackmar, K., \& Williams, L. J. (2000). Construction and initial validation of a multidimensional measure of workfamily conflict. Journal of Vocational Behavior, 56(2), 249-276. doi:10.1 006/jvbe.1999.1713.

Carroll, S. J., Hill, E. J., Yorgason, J. B., Larson, J. H., \& Sandberg, J. G. (2013). Couple communication as a mediator between work-family conflict and marital satisfaction. Contemporary Family Therapy, 35(3), 530-545. doi:10.1007/ s10591-013-9237-7.

Chen, L. H. \& Li, T. S. (2012). Role balance and marital satisfaction in taiwanese couples: An actor-partner interdependence model approach. Social Indicator Research, 107(1), 187-199. doi:10.1007/s11205-0119836-3.

Creary, S. J., \& Gordon, J. R. (2016). Role conflict, role overload, and role strain: Encyclopedia of family studies. Hoboken, $\mathrm{NJ}$ : John Wiley \& Sons, Inc.

Deepa, D. (2019). Personality Aging Pattern (PAP): An empirical study on personality traits in relation with work force age bands. Shanlax International Journal of Management, 7(1), 57-60. doi:https://doi. org/10.34293/ management.v7i1.563.

Evers, A., \& Sieverding, M. (2013). Why do Highly qualified women (still) earn less? Gender differences in long-term predictors of career success. Psychology of Women Quarterly, 38(1), 93-106. doi:10.1177/ 0361684313498071.

Fallahchai, R., Fallahi, M., \& Randall, A. K. (2019). A dyadic approach to understanding associations between job stress, marital quality, and dyadic coping for dual-career couples in Iran. Frontiers in Psychology, 10(487), 1-32. doi:10.3389/ fpsyg.2019.00487.

Fellows, K. J., Chiu, H. Y., Hill, E. J., \& Hawkins, A. J. (2015). Work-family conflict and couple relationship quality: A metaanalytic study. Journal of Family and Economic Issues, 37(4), 509518. doi:10.1007/s10834-015-9450-7.

Ferguson, M., Carlson, D., Kacmar, K. M., \& Halbesleben, J. R. B. (2016). The supportive spouse at work: Does being 
work-linked help?. Journal of Occupational Health Psychology, 21(1), 3750. doi:10.1037/a0039538.

Ferguson, M., Carlson, D., Zivnuska, S., \& Whitten, D. (2012). Support at work and home: The path to satisfaction through balance. Journal of Vocational Behavior, 80(2), 299-307. doi:10.1016/j.jvb .2012 .01 .001 .

Fincham, F. D. \& Rogge R. (2010). Understanding relationship quality : Theoretical challenges and new tools of assessment. Journal of Family Theory \& Review, 2(4), 227-242. doi:10.1111/j.17562589.2010.00059.x.

Fincham, F. D., Rogge, R., \& Beach, S. R. H. (2018). Relationship satisfaction. In A. L. Vangelisti \& D. Perlman (Eds.), The Cambridge handbook of personal relationships (p. 422-436). Cambridge, UK: Cambridge University Press.

Finkel, E. J., Slotter, E. B., Luchies, L. B., Walton, G. M., \& Gross, J. J. (2013). A brief intervention to promote conflict reappraisal preserves marital quality over time. Psychological Science, 24(8), 15951601. doi:10.1177/0956797612474938.

Frone, M. R. (2003). Work-family balance. In J. C. Quick \& L. E. Tetrick (Eds.). Handbook of occupational health psychology (pp. 143-162). Washington D.C, US: American Psychological Association.

Funk, J. L., \& Rogge, R. D. (2007). Testing the ruler with item response theory: Increasing precision of measurement for relationship satisfaction with the couples satisfaction Index. Journal of Family Psychology, 21(4), 572-583. doi:10.1037/08933200.21 .4 .572 .

Gravetter, F. J. \& Forzano, L. B. (2012). Research methods for the behavioral sciences 4th edition. Boston, US: Wadsworth Cengage Learning.

Greenhaus, J. H., \& Beutell, N. J. (1985). Sources of Conflict between work and family roles. The Academy of Management Review, 10(1), 76. doi:10.2307/258214.

Handayani, N. S, \& Harsanti, I. (2017). Kepuasan pernikahan: Studi pengaruh konflik pekerjaan-keluarga pada wanita bekerja. Jurnal Ilmiah Psikologi Gunadarma, 10(1), 92-99.

Heshmati, H., Behnampour, N., Arabameri, S., Khajavi, S., \& Kohan, N. (2016). Marital satisfaction in refereed women to gorgan health centers. Iranian Journal of
Psychiatry
11(3),
198-200. doi:27928253/PMC5139956.

Keene, J. R., \& Reynolds, J. R. (2005). The job costs of family demands. Journal of Family Issues, 26(3), 275-299. doi:10.1177/0192513×04270219.

Langdon, R. R., \& Sawang, S. (2018). Construction workers' well-being: What leads to depression, anxiety, and stress?. Journal of Construction Engineering and Management, 144(2), 115. doi:10.1061/(asce)co.1943-

7862.0001406 .

Leikas, S., \& Salmela-Aro, K. (2014). Personality trait changes among young Finns: The role of life events and transitions. Journal of Personality, 83(1), 117-126. doi:10.1111/jopy.12088.

Liu, Y., Wang, M., Chang, C.-H., Shi, J., Zhou, L., \& Shao, R. (2015). Work-family conflict, emotional exhaustion, and displaced aggression toward others: The moderating roles of workplace interpersonal conflict and perceived managerial family support. Journal of Applied Psychology, 100(3), 793-808. https://doi.org/10.1037 /a0038387.

Masterson, C. R., \& Hoobler, J. M. (2014). Care and career: A family identity-based typology of dual-earner couples. Journal of Organizational Behavior, 36(1), 7593. doi:10.1002/job. 1945.

Melissa. (2015). Hubungan antara materialisme dan dimensi kompetensi interpersonal dengan kepuasan hubungan pada emerging adulthood yang akan menikah di Jakarta Barat (Skripsi). Jakarta, ID: Universitas Bina Nusantara.

Mercado, B. K., \& Dilchert, S. (2017). Family interference with work and its relationship with organizational citizenship and counterproductive work behaviors. International Journal of Selection and Assessment, 25(4), 406-415. doi:10.1111 /ijsa.12195.

Minnotte, K. L., Minnotte, M. C., \& Bonstrom, J. (2014). Work-family conflicts and marital satisfaction among US workers: Does stress amplification matter?. Journal of Family and Economic Issues, 36(1), 2133. doi:10.1007/s10834-014-9420-5.

Molina, J. A. (2015). Caring within the family: Reconciling work and family life. Journal of Family and Economic Issues, 36(1), 14. doi:10.1007/s10834-015-9441-8. 
Nohe, C., Meier, L. L., Sonntag, K., \& Michel, A. (2015). The chicken or the egg? A metaanalysis of panel studies of the relationship between work-family conflict and strain. Journal of Applied Psychology, 100(2), 522-536. doi:10.1037/a0038012.

Norton, R. (1983). Measuring marital quality: A critical look at the dependent variable. Journal of Marriage and Family, 45(1), 141-151. doi: 10.2307/351302.

Omar, M. K., \& Zakaria, A. (2015). Conceptualising work-life balance: Extension of work-family balance. Advanced Science Letters, 21(6), 21552158. doi:10.1166/asl.2015.6240.

Papalia, D. E., \& Martorell, G. (2014). Experience human development (12th ed.). New York, US: McGraw Hill Education.

Park, Y., \& Fritz, C. (2015). Spousal recovery support, recovery experiences, and life satisfaction crossover among dual-earner couples. Journal of Applied Psychology, 100(2), 557-566. doi:10.1037/a0037894.

Pattusamy, M., \& Jacob, J. (2015). Testing the mediation of work-family balance in the relationship between work-family conflict and job and family satisfaction. South African Journal of Psychology, 46(2), 218231. doi:10.1177/0081246315608527.

Pedersen, D. E., \& Kilzer, G. (2013). Work-tofamily conflict and the maternal gatekeeping of dual-earner mothers with young children. Journal of Family and Economic Issues, 35(2), 251262. doi:10.1007/s10834-013-9370-3.

Pluut, H., Ilies, R., Curşeu, P. L., \& Liu, Y. (2018). Social support at work and at home: Dual-buffering effects in the workfamily conflict process. Organizational Behavior and Human Decision Processes, 146(2018), 1-13. doi:10.1016/j.obhdp .2018.02.001

Poms, L. W., Fleming, L. C., \& Jacobsen, K. H. (2016). Work-family conflict, stress, and physical and mental health: A model for understanding barriers to and opportunities for women's well-being at home and in the workplace. World Medical \& Health Policy, 8(4), 444-457. doi:10.1002/wmh3.211.

Sakina, A. I., \& Asiah, D. H. (2017). Menyoroti budaya patriarki di Indonesia. Social Work Journal, 7(1), 71-80. doi:https://doi.org /10.24198/share.v7i1.13820.

Santa-Maria, A., Wörfel, F., Wolter, C., Gusy, B., Rotter, M., Stark, S., Renneberg, B.
(2017). The role of job demands and job resources in the development of emotional exhaustion, depression, and anxiety among police officers. Police Quarterly, 21(1), 109-134. doi:10.1177/1098611 117743957.

Steil, J. M. (2009). Dual-earner couples. In Reis, H. T. \& Sprecher, S. (Eds.) Encyclopedia of human relations. (pp. 2954). Thousand Oaks, CA: Sage.

Tazekand, F. E., Nafar, N., \& Keramati, R. (2013). The relationship between marital satisfaction and job satisfaction among employees of social welfare organization at Tehran Branches. Life Science Journal, 10(6s), 804-812. doi:10.7537/marslsj $1006 s 13.127$.

Toffoletti, K., \& Starr, K. (2016). Women academics and work-life balance: Gendered discourses of work and care. Gender, Work \& Organization, 23(5), 489504. doi:10.1111/gwao.12133.

VanSteenbergen, E. F., Kluwer, E. S., \& Karney, B. R. (2014). Work-family enrichment, work-Family conflict, and marital satisfaction: A dyadic analysis. Journal of Occupational Health Psychology, 19(2), 182 - 194. doi:10.10 37/a0036011.

Waismel-Manor, R., Levanon, A. \& Tolbert, P.S. (2016). The impact of family economic structure on dual-earners' career and family satisfaction. Sex Roles, 75(78), 349-362. doi:10.1007/s11199-0160620-3.

Wortel, C. (2009). The relation of work-family conflict and work-family facilitation with marital satisfaction, through negative and positive behaviors (Master's Thesis). Utrecht, NL: Universiteit Utrech.

Xie, J., Shi, Y., \& Ma, H. (2017). Relationship between similarity in work-family centrality and marital satisfaction among dual-earner couples. Personality and Individual Differences, 113(2017), 103-108. doi:10. 1016/j.paid.2017.03.021

Yucel, D. (2017). Work-family Balance and Marital Satisfaction: The mediating effects of mental and physical health. Society and Mental Health, 7(3), 175-195. doi:10.1177/ 2156869317713069.

Zaimah, R. (2019). The probability factor influences the level of financial well-being of workers in Malaysia. Malaysian Journal of Society and Space, 15(3), 122-135. doi:10.17576/geo-2019-1503. 